\title{
Differences in lymphocyte subpopulation count and function in cord, maternal and adult blood
}

\author{
Kordon kanı, maternal ve erişkin kanda sayısal ve fonksiyonel \\ lenfosit alt grup farklılıkları \\ Nilgün Akdeniz, Esin Aktaş, Gaye Erten, Sema Bilgiç, Günnur Deniz \\ Department of Immunology, Institute of Experimental Medicine, Istanbul University, Istanbul, Turkey
}

\begin{abstract}
Objective: Phenotypical characterization and functional activity of lymphocytes and natural killer (NK) cells in cord blood (CB) were investigated, and maternal peripheral blood (MPB) values were compared to those of adult peripheral blood (APB) (control).

Materials and Methods: To determine cytotoxic activity target cells (K562) were labeled with carboxyfluorescein diacetate (CFDA) or fluorescein isothiocyanate (FITC), and propidium iodide (PI) was used to label dead cells. Cell surface expression in CB, APB, and MPB cells were analyzed using flow cytometry.

Results: CB and MPB mononuclear cells had similar CD45, CD34, CD4, and surface molecule for T helper cell expression, but had low-level expression of total T-lymphocyte surface molecules CD3 and CD8. CD19 and HLA-DR expression was higher in CB than in MPB. The same high-level of expression for CD19 and HLA-DR was observed in APB, as compared to MPB. All other cell surface expressions were similar in APB and MPB samples. NK $\left(\mathrm{CD} 16^{+}\right.$and $\left.\mathrm{CD}^{+} 6^{+}\right)$cells in $\mathrm{CB}$ was similar to that in MPB and APB, and the level of inhibitory KIR receptors in NK cells was higher in venous CB than in MPB and APB. The only difference between MPB and APB was that the CD158a level was higher in MPB. No difference was observed in NK cells in CB and MPB, in terms of cytotoxicity.

Conclusion: The present results show that there was numerical and proportional variability of lymphocytes and their subgroups in CB and APB, but no cytological difference. (Turk J Hematol 2011; 28: 33-41) Key words: NK activity, cord blood lymphocytes, flow cytometry
\end{abstract}

Received: September 10, 2009

Accepted: April 30, 2010

\section{Özet}

Amaç: Kordon kanındaki lenfosit ve NK hücrelerinin fonksiyonel aktivitesi ve fenotipik karakterizasyonu araştırılmış, anne kan değerleri (MPB) kontrol olarak erişkin periferik kan (APB) değerleri ile karşılaştırılmıştır. 
Yöntem ve Gereçler: Sitotoksik aktivite için hedef hücreler (K562) karboksifloresandiasetat (CFDA) veya floresanizotiyosiyanat (FITC) ile işaretlenmiş, ölü hücreler ise propidiumiyodid (PI) ile saptanmıştır. Kordon, anne ve erişkin periferik kan hücre yüzey ifadeleri flow sitometri ile analiz edilmiştir. Bulgular: Kordon kanı CD45, CD34 ve CD4 ifadesi açısından maternal periferik kana benzerlik gösterirken, CD3 ve CD8 ifadesi düşük, CD19 ve HLA-DR ifadeleri ise kordon kanında maternal kana göre yüksek saptanmıştır. Maternal kana göre CD19 ve HLA-DR açısından benzer yüksek ifade erişkin kanda da gözlenmiş, diğer tüm yüzey ifadeleri erişkin ve maternal örneklerde benzer olarak saptanmıştır. Kordon kanı NK $\left(\mathrm{CD} 16^{+} \mathrm{CD}^{+} 6^{+}\right)$hücreleri maternal ve erişkin kana benzerlik gösterirken, NK hücre yüzeyinde aktivatör CD161 ve inhibitör anti-Hu-KIR ifadesi hem maternal hem de erişkin kana göre, CD158a ifadesi ise sadece erişkin kana göre yüksek saptanmıştır. Erişkin ve maternal kan karşılaştırıldığında sadece CD158a ifadesi maternal kanda yüksek olarak bulunmuştur. Kordon, erişkin ve maternal kan örneklerinde NK sitotoksisitesi açısından farklılık gözlenmemiştir.

Sonuç: Bulgularımız lenfosit ve altgrupları açısından kordon kanı ile yetişkin immün sistem arasında sayı ve fonksiyonel anlamda farklılık olduğunu göstermekle birlikte, sitotoksik aktivite açısından bir farklılık olmadığını ortaya koymaktadır.(Turk J Hematol 2011; 28: 33-41)

Anahtar kelimeler: NK aktivitesi, kordon kanı lenfositleri, flow sitometri

Geliş tarihi: 10 Eylül 2009

Kabul tarihi: 30 Nisan 2010

\section{Introduction}

Allogeneic cord blood transplantation (CBT), especially from unrelated donors, has become an extensively used treatment for patients with both malignant and nonmalignant disorders [1]. As compared to bone marrow transplantation (BMT), the advantages of CBT include ease and safety of hematopoietic collection, low risk of viral contamination, prompt availability when an unrelated donor is used, and reductions in the incidence and severity of graft-versus-host disease (GVHD) [2,3].

Several immunologic properties and peculiarities of cord blood lymphocytes (CBL) may be responsible for the reduction of GVHD following CBT [4]. In fact, CBLs are naive and characterized by a low number of interleukin-2 (IL-2), interferon (IFN)- $\gamma$, and tumor necrosis factor (TNF)- $\alpha$ producing cells, and have been shown to produce lower quantities of proinflammatory cytokines, such as IFN- $\gamma$ and TNF- $\alpha$, and to display no or markedly reduced responsiveness to allogeneic stimuli in a secondary mixed lymphocyte reaction (MLR) [5,6]. One of the reasons for the lower incidence of GVHD may be the reduced cytotoxic potential of cord blood (CB)-derived natural killer (NK) and cytotoxic $\mathrm{T}$ cells, as well as reduced levels of T helper 1 (Th1) cytokines, which are known to take part in the GVHD mechanistic cascade [7-10]. On the other hand, cytotoxic T and NK cells are the key effector cells that mediate the graft-versus-leukemia (GVL) effect, which are used clinically in adoptive cellmediated immunotherapy to control minimal residual disease and for re-induction of remission in chronic myelogenous leukemia patients that relapse following allogeneic stem cell transplantation (alloSCT) [11-13].

Most clinical experimental data indicate that the greater the GVL affect after alloSCT, the higher the risk of developing GVHD [14,15]. Reducing the risk of GVHD after alloSCT, either by T cell depletion or by immunosuppression, is known to lead to an increase in leukemic relapse, which may indicate a decrease in the GVL effect $[16,17]$. As such, one of the main concerns in CBT was that the reduced incidence of GVHD observed following CBT would lead to a decrease in the GVL effect and a subsequent increase in the relapse rate. Nevertheless, it has been shown that CB-derived NK and lymphokine-activated killer cells are able to lyse non-cultured fresh leukemia blasts, readily respond to IL-2 and IL-12, and mediate relatively high levels of apoptosis-mediated cytotoxicity against target cell lines $[18,19]$.

Furthermore, CB is rich in unique NK cell subsets that may possess greater potential proliferative capacity than adult peripheral blood (APB) NK cells [20]. NK cells in CB appear to be similar to those in $\mathrm{APB}$, and these cells may actually have greater proliferative capacity when exposed to alloantigens or exogenous cytokines [8,18,21]. This suggests that CB may have substantial GVL potential and that CB- 
derived NK cells may be used effectively, if properly amplified, for adoptive cell-mediated immunotherapy and amplification of the GVL effect.

The function of NK cells is important for the clearance of tumor cells, the removal of immunoglobulin-bound antigens, and the control of viral infections [22]. It was reported that NK function is decreased in some patients, including those with primary immunodeficiencies, those with late-stage human immunodeficiency virus (HIV) infection, and pregnant women [23,24]. NK cell function is tightly regulated by a fine balance of inhibitory and activatory signals that are delivered by a diverse array of cell surface receptors. Killer cell Ig-like receptor (KIR) binds to HLA class I molecules on the surface of target cells, and it confers inhibitory signals to NK cells $[25,26]$. Upon its ligation by HLA class I molecules, KIR can deliver inhibitory signals via the immune-receptor tyrosine-based inhibitory motif. As such, NK cells can recognize cells that do not express HLA class I molecules as cytotoxic target cells, and KIR plays a role in NK cells' cytotoxic target discrimination $[27,28]$. Among the inhibitory receptors, some are specific for different groups of MHC class I alleles, while others are orphan receptors. In contrast, various activating receptors are involved in the triggering of NK cell-mediated natural cytotoxicity [25].

The present study analyzed activatory KIR: CD161 (NKR-P1A), and inhibitory KIRs: CD158a (NKAT1, KIR2DL1) and anti-human KIR (NKB1). As more is learned about NK cells and their function, and more simplified and precise means to quantify their numbers and functions become available, analysis of lymphocytes from healthy human controls and patients may become a more routine practical approach in clinical trials. Moreover, low-level NK cell activity may be useful for predicting patient outcome [23]; therefore, a suitable clinical assay for NK cell activity is necessary.

The role of the functional and phenotypic characteristics of CB lymphocytes and NK cell activity against K562 in CB were investigated and compared to that in maternal peripheral blood (MPB) and APB (control). Target cells were labeled with fluorescein isothiocyanate (FITC) or carboxyfluorescein diacetate (CFDA) before contact with effector cells. The red fluorescent dye propidium iodide (PI) was applied for the identification of dead cells.

\section{Materials and Methods}

\section{Study population}

CB samples $(n=10)$ were obtained immediately postpartum from full-term, normally delivered healthy babies via cannulation of the umbilical vein and collected into heparinized tubes. Then, mononuclear cell fraction of CBL was obtained via FicollHypaque (Sigma Chemical Co., St Louis, MO, USA) density-gradient centrifugation. Mononuclear cell fractions of heparinized MPB (derived from healthy maternal donors $[n=10]$ ) and APB (derived from adult healthy donors $[n=10]$ ) were also separated by the same procedure described above. The viability of separated CB, MPB, and APB lymphocytes was measured using Trypan blue. The study protocol was approved by the Istanbul University Ethics Committee.

\section{Flow cytometric analysis}

\section{Assay of cell surface markers}

Mononuclear cells $\left(2 \times 10^{5}\right.$ cells $\left.\mathrm{mL}^{-1}\right)$ were stained with anti-CD45-FITC/anti-CD14-PE, antiCD3-FITC, anti-CD19-PE, anti-CD4-FITC, anti-CD8PE, anti-CD16/56-PE, anti-HLA-DR-PE, anti-CD158aFITC, anti-CD161-FITC, anti-human KIR (NKB1)FITC, and anti-CD34-FITC (all obtained from Becton Dickinson, San Jose, USA). Stained cells were fixed in $2 \%$ paraformaldehyde. The controls were FITCand PE-conjugated mouse IgG1 and IgG2A (Becton Dickinson, San Jose, USA). Flow cytometric analysis was performed using FACSCalibur (Becton Dickinson, San Jose, USA).

\section{Cytotoxic activity}

\section{Target cell}

The cell line K562, an NK-sensitive tumoral human erythroleukemia cell line, was used as target cells. Cells were grown in RPMI-1640 (GibcoBRL, UK) supplemented with 10\% fetal bovine serum (FBS, Dutscher, France) and cultured for $24 \mathrm{~h}$ before cytometric analysis. 


\section{Cell labeling}

Two fluorescent dyes were initially tested for labeling target cells: FITC (Sigma Chemical Co., St Louis, MO, USA) at $50 \mu \mathrm{g} \mathrm{mL}-1$ in PBS and CFDA (Sigma Chemical Co., St Louis, MO, USA) at $30 \mu \mathrm{g} \mathrm{m}$ $\mathrm{L}^{-1}$ in PBS. For FITC and CFDA labeling, target cells were adjusted to $10^{5}$ cells $\mathrm{m} \mathrm{L}^{-1}$ in PBS, incubated for $30 \mathrm{~min}$ at $37^{\circ} \mathrm{C}$, and then rinsed 2 times with PBS. Cell viability was assessed using PI (Sigma Chemical Co., St Louis, MO, USA), which permeates only through the membrane of dead cells and emits a red fluorescence ( $10 \mu \mathrm{L} \mathrm{mL}^{-1}$ is the optimal concentration determined after a calibration assay).

\section{Effector cells}

$\mathrm{CB}, \mathrm{MPB}$, and APB mononuclear cells were obtained from heparinized blood via density gradient centrifugation over Ficoll (Sigma Chemical Co., St Louis, MO, USA), and were used as the source of NK effector cells. These effector cells were washed twice with RPMI-1640 medium (Sigma Chemical Co., St Louis, MO, USA) and resuspended to a final concentration of $5 \times 10^{6}$ cells $\mathrm{mL}^{-1}$ for NK assay.

\section{Cytotoxicity}

Effector and target cells were placed in $12 \times 75$ $\mathrm{mm}$ round bottom polystyrene tubes (Falcon, NJ, USA) to yield effector:target ratios of 50:1, 25:1, and 12.5:1. Control tubes that included only target cells were assayed to identify spontaneous cell death. For maximum lysis ( $100 \%$ of death) target cells were incubated with $0.1 \%$ Triton X-100 (Sigma Chemical Co., St Louis, MO, USA). To enhance cell contact the mixture was centrifuged at $800 \mathrm{rpm}$ for 1-2 min, and then incubated as a cell pellet in complete medium for $4 \mathrm{~h}$ at $37{ }^{\circ} \mathrm{C}$ under $5 \% \mathrm{CO}_{2}$. After incubation, $10 \mu \mathrm{L} \mathrm{mL}-1$ of PI was added to each tube for detection of dead cells, and cooled for 5-10 min on ice before acquisition. The samples were gently mixed and analyzed using flow cytometry (FACSCalibur, Becton Dickinson, San Jose, USA). Forward and side scatter parameters were adjusted to accommodate the inclusion of both target and effector cells within the acquisition gate. No cells were excluded from the analysis, and 10,000 cells were counted. Data were analyzed using BD FACSCalibur with CellQuest software (BD Bioscience, San Jose, USA).

\section{Statistical analysis}

Data are expressed as mean \pm standard deviation (SD). Statistical analysis was performed by Student's t test using SPSS 11.5 version

\section{Results}

\section{Expression of cell surface molecules}

To characterize the subpopulations of cells undergoing expansion cells were stained with $\mathrm{T}$ and NK cell-associated surface markers, and flow cytometric analysis was performed. Table 1 summarizes the percentage of lymphocyte subsets observed in $\mathrm{CB}, \mathrm{MPB}$, and $\mathrm{APB}$ with a viability $>95 \%$. In MPB and CB mononuclear cells total leukocyte marker CD45, and stem cell marker CD34 and CD4 (marker for helper T cells) expression were similar $(p=0.068, p=0.075, p=0.059$, respectively); however, CD3, total T cell marker, and CD8 (a marker for cytotoxic T cells) were significantly lower in CB ( $p=0.046, p=0.012$, respectively, Figure 1A). Expression of the B-lymphocyte marker CD19 and activation marker HLA-DR were significantly higher in CB than in MPB $(p=0.0089, p=0.0014$, respectively, Figure 1A). Expression of CD19 and HLA-DR were also significantly higher in APB than in MPB; however, there wasn't a significant difference in the expression of CD3 and CD8 between APB and MPB ( $p=0.019, p=0.0085$, respectively).

$\mathrm{CD}_{16}+$ and $\mathrm{CD} 56+\mathrm{NK}$ cell expression was similar in CB, MPB, and APB samples; however, activatory KIR CD161, and CD158a, and Hu-KIR cell surface molecules, which are inhibitory KIR receptors in NK cells, were more highly expressed in venous CB than in MPB $(p=0.0021, p=0.0068, p=0.036$, respectively, Figure $1 \mathrm{~B}$ ). Compared to $\mathrm{MPB}$, only CD158a expression was significantly lower in APB and there wasn't a difference in the expression of CD161 and anti-Hu-KIR ( $p=0.0046)$.

\section{Flow cytometric assay for NK cytotoxicity}

The cytotoxic potential of CB, MPB, and APB was analyzed via direct cytotoxic activity in NK-sensitive K562 cells. A flow cytometry-based assay, which correlates well with the standard chromium-release assay, was used [29]. Cells from CB, MPB, and APB were used as effector cells against the labeled target cells (K562) with 2 differ- 
Table 1 A. Lymphocyte subsets in CB and MPB

\begin{tabular}{lccc}
\hline $\begin{array}{l}\text { Surface } \\
\text { molecules }\end{array}$ & CB & MPB & P \\
\hline $\mathrm{CD}^{+} 5^{+}$ & $97.2 \pm 1.5$ & $98.2 \pm 0.5$ & $\mathrm{p}=0.068$ \\
$\mathrm{CD}^{+}$ & $63.8 \pm 3.6$ & $73.2 \pm 5.2$ & $\mathrm{p}=0.046$ \\
$\mathrm{CD}^{+}$ & $47.0 \pm 9.0$ & $41.4 \pm 5.4$ & $\mathrm{p}=0.059$ \\
$\mathrm{CD}^{+}$ & $23.8 \pm 5.2$ & $36.8 \pm 4.7$ & $\mathrm{p}=0.012$ \\
$\mathrm{CD}^{+} 9^{+}$ & $17.6 \pm 5.4$ & $9.6 \pm 0.8$ & $\mathrm{p}=0.0089$ \\
$\mathrm{HLA}^{+} \mathrm{DR}^{+}$ & $19.2 \pm 6.4$ & $8.2 \pm 4.0$ & $\mathrm{p}=0.0014$ \\
$\mathrm{CD}^{+} 4^{+}$ & $1.6 \pm 1.1$ & $1.0 \pm 0.4$ & $\mathrm{p}=0.075$ \\
$\mathrm{CD}^{+} 6^{+} 56^{+}$ & $20.0 \pm 6.6$ & $18.0 \pm 6.6$ & $\mathrm{p}=0.094$ \\
$\mathrm{CD}^{+} 61^{+}$ & $30.2 \pm 7.0$ & $15.6 \pm 3.0$ & $\mathrm{p}=0.0021$ \\
$\mathrm{CD}^{+} 58 \mathrm{a}^{+}$ & $8.2 \pm 2.5$ & $4.4 \pm 1.1$ & $\mathrm{p}=0.0068$ \\
\hline Hu-KIR & $5.6 \pm 0.4$ & $2.8 \pm 1.3$ & $\mathrm{p}=0.036$ \\
\hline
\end{tabular}

Lymphocyte subsets in CB, MPB, and APB. Phenotypic analysis of lymphocytes isolated from $\mathrm{CB}, \mathrm{MPB}$, and $\mathrm{APB}$. The percentage of positive cells was determined using FACSCalibur. The results are given as mean $\% \pm$ SD

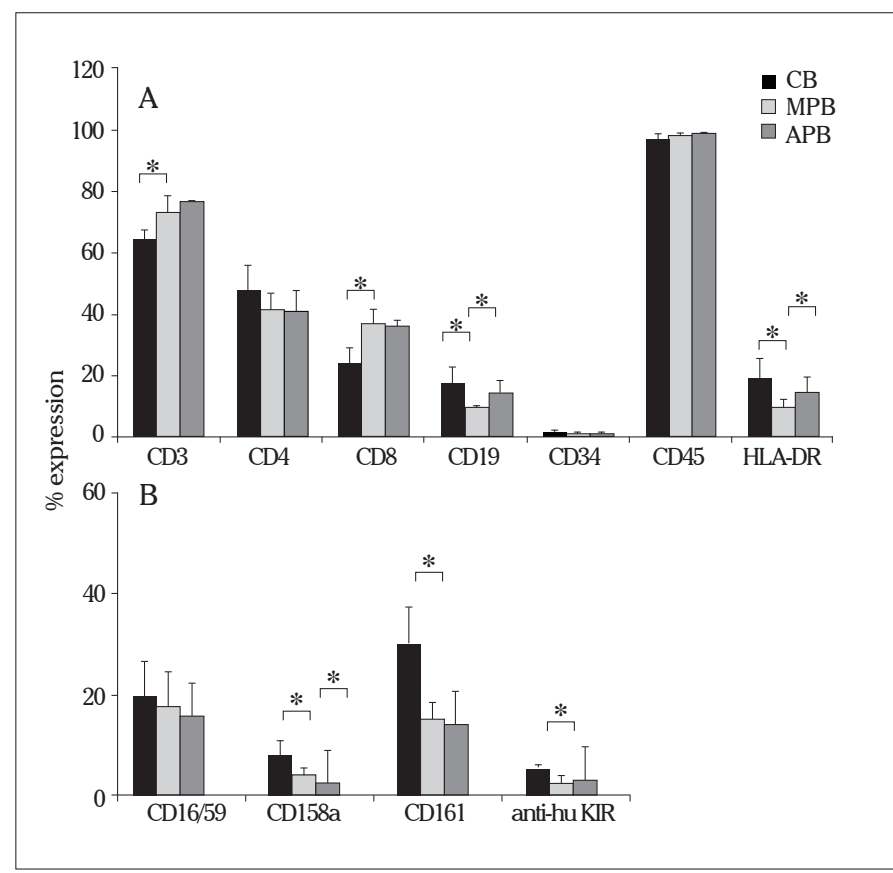

Figure 1. (A-B) Expression of lymphocyte surface molecules, and NK and KIR receptors in CB and MPB.

ent dyes, namely CFDA and FITC. Dead cells were identified base on PI incorporation. Effector and target cells were mixed at ratios of 12.5:1, 25:1, and $50: 1$, and co-incubated for $4 \mathrm{~h}$ at $37^{\circ} \mathrm{C}$ under a $5 \%-\mathrm{CO}_{2}$ atmosphere; the results are shown in Table 2. Cytotoxic activity of CB, MPB, and APB increased in an effector:target ratio-dependent manner, and cytotoxicity increased as the number
Table 1 B. Lymphocyte subsets in APB and MPB.

\begin{tabular}{lccc}
\hline $\begin{array}{l}\text { Surface } \\
\text { molecules }\end{array}$ & APB & MPB & P \\
\hline $\mathrm{CD}^{+} 5^{+}$ & $98.7 \pm 0.6$ & $98.2 \pm 0.5$ & $\mathrm{p}=0.073$ \\
$\mathrm{CD}^{+}$ & $76.0 \pm 0.8$ & $73.2 \pm 5.2$ & $\mathrm{p}=0.056$ \\
$\mathrm{CD}^{+}$ & $41.0 \pm 6.5$ & $41.4 \pm 5.4$ & $\mathrm{p}=0.078$ \\
$\mathrm{CD}^{+}$ & $36.0 \pm 2.0$ & $36.8 \pm 4.7$ & $\mathrm{p}=0.076$ \\
\hline $\mathrm{CD}^{+}$ & $14.0 \pm 4.3$ & $9.6 \pm 0.8$ & $\mathrm{p}=0.019$ \\
\hline $\mathrm{HLA}^{+}$ & $14.7 \pm 4.8$ & $8.2 \pm 4.0$ & $\mathrm{p}=0.0085$ \\
\hline $\mathrm{CD}^{+}$ & $1.1 \pm 0.4$ & $1.0 \pm 0.4$ & $\mathrm{p}=0.095$ \\
\hline $\mathrm{CD}^{+}$ & $16.0 \pm 6.5$ & $18.0 \pm 6.6$ & $\mathrm{p}=0.088$ \\
\hline $\mathrm{CD}^{+} 56^{+}$ & $14.3 \pm 3.0$ & $15.6 \pm 3.0$ & $\mathrm{p}=0.0965$ \\
\hline $\mathrm{CD}^{+}$ & $2.7 \pm 0.6$ & $4.4 \pm 1.1$ & $\mathrm{p}=0.0046$ \\
\hline Hu-KIR & $3.3 \pm 1.2$ & $2.8 \pm 1.3$ & $\mathrm{p}=0.098$ \\
\hline
\end{tabular}

Lymphocyte subsets in CB, MPB, and APB. Phenotypic analysis of lymphocytes isolated from $\mathrm{CB}, \mathrm{MPB}$, and $\mathrm{APB}$. The percentage of positive cells was determined using FACSCalibur. The results are given as mean $\% \pm \mathrm{SD}$

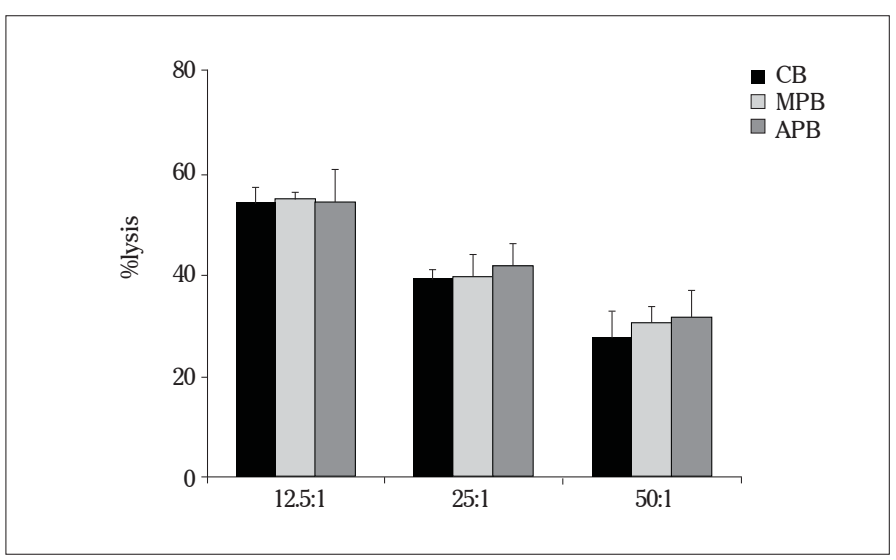

Figure 2. Cytotoxic activity in $\mathrm{CB}, \mathrm{MPB}$, and $\mathrm{APB}$

of effector cells increased; however, there wasn't a significant difference between $\mathrm{CB}, \mathrm{MPB}$, and $\mathrm{APB}$ cells, in terms of cytotoxic activity.

\section{Discussion}

CB T cells have been studied since it was demonstrated that recipients of related and unrelated umbilical CBT experience less acute and chronic GVHD than recipients of BMT [30]. The major theory regarding the reduced immunological response of CB lymphocytes is that $\mathrm{CB} \mathrm{T}$ and NK cells are naive and exhibit decreased cytokine production and are therefore not primed for activation [31].

In the present study immunophenotypic characterization of $\mathrm{CB}$ mononuclear cells and cytotoxic activity of NK cells in $\mathrm{CB}$ were investigated. The 
Table 2. The cytotoxic effect of effector cells on FITC-labeled and CFDA-labeled K562 target cells

\begin{tabular}{lcccccc}
\hline & \multicolumn{2}{c}{ 12.5:1 } & \multicolumn{2}{c}{ 25:1 } & \multicolumn{2}{c}{ 50:1+ } \\
& FITC & CFDA & FITC & CFDA & FITC & CFDA \\
\hline APB & $52.0 \pm 3.2$ & $54.7 \pm 6.5$ & $42.0 \pm 1.5$ & $42.0 \pm 4.0$ & $29.0 \pm 3.5$ & $32.0 \pm 5.0$ \\
MPB & $54.8 \pm 1.5$ & $56.0 \pm 3.7$ & $40.0 \pm 3.8$ & $42.0 \pm 6.7$ & $30.4 \pm 3.4$ & $29.6 \pm 6.0$ \\
CB & $54.2 \pm 3.0$ & $52.0 \pm 6.6$ & $39.2 \pm 2.0$ & $38.9 \pm 5.2$ & $27.6 \pm 5.1$ & $27.0 \pm 5.2$ \\
\hline
\end{tabular}

The cytotoxic effect of effector cells on FITC-labeled and CFDA-labeled K562 target cells. NK cytotoxic activity in CB and MPB at different effector: target ratios (12.5:1, 25:1, and 50:1) is shown as mean $\% \pm \mathrm{SD}$

phenotypic subsets of CB lymphocytes differed significantly from those of MPB lymphocytes; In comparison to MPB cells, higher expression of B-lymphocyte surface molecules, CD19, and the activation molecule HLA-DR, and lower expression of CD3 and CD8 were observed in CB cells. Similar to $\mathrm{CB}$, lower expression of CD19 and HLA-DR was also noted in APB than in MPB; however, CD3 and CD8 did not differ significantly. The observed decrease in the ratio of total T-lymphocytes was proportional to the decrease in the ratio of cytotoxic T-lymphocytes, and low CD3 expression may be considered indicative of immature T-lymphocytes during the intermediate phase. There wasn't a statistically significant difference in the expression of CD4 as a surface molecule for $\mathrm{T}$ helper cells between $\mathrm{CB}$ and MPB. In contrast to the present results, it has been reported that $\mathrm{CB}$ contains a higher absolute number of T, NK, and B cells than MPB. The same higher expression of NK cells was observed even in CB obtained during caesarean sections than in $\mathrm{CB}$ obtained during vaginal deliveries, indicating variability in NK cell numbers according to the type of delivery [32]. In $\mathrm{CB}$ a relative excess of naive cells among $\mathrm{T}$ cells and in the $\mathrm{CD} 4^{+}$ and $\mathrm{CD}^{+}{ }^{+}$subsets individually were reported. Similarly, the B-lymphocyte compartment had a smaller fraction of memory IgE receptor (CD23)positive cells, along with a higher percentage of the so-called $\mathrm{B} 1$ ontogenetically more primitive $\mathrm{CD} 19^{+}$/ $\mathrm{CD}^{+} \mathrm{B}$ cells [33,34]. A smaller fraction of CB T cells exhibited markers of peripheral activation, such as HLA-DR, or the CCR5 subset performing tissue surveillance in the skin was absent, which may also explain the lower incidence of skin GVHD after CBT [35].

In the present study $\mathrm{CB}$ the $\mathrm{NK}\left(\mathrm{CD} 16^{+} / \mathrm{CD} 56^{+}\right)$ cell ratio was similar to the MPB NK cell ratio, as was previously reported for NK cells in APB and CB
[36]. The nature of CB NK cells remains controversial; despite the similar frequency of NK cells in $\mathrm{CB}$ and APB, CB NK cell dysfunction, as compared to APB and MPB was reported. In contrast, NK cells differentiated from CB stem cells exhibited comparable cytotoxicity as those from bone marrow or APB stem cells [37]. Although NK cell counts in CB were higher, cytotoxic activity was reported to be lower in some studies, and CB T-lymphocytes were immature and their cytotoxic activity was insufficient. Other possible mechanistic explanations for the reduction in killing by CB NK cells include relatively higher expression of inhibitory receptor complexes, including CD94/NKG2A and/or KIR [38]. This KIR is expressed in 10\%-30\% of CB NK cells and in the present study compared to MPB the observed higher expression of CD161, CD158a, and antihuman-KIR in CB supports the protective role of $\mathrm{CB}$ in GVHD. Some studies suggest that expression of NK cells triggering receptors, including CD94, KIR (CD158a/h and CD158b/j), NKp46, and NKG2D, does not differ between CB and APB NK cells, while others reported that a higher percentage of CB NK cells express the inhibitory receptor complex of CD94/ NKG2A and CD158b/j [38,39]. Considering the role of T-lymphocytes and NK cells in the pathophysiology of GVHD, the reported lower incidence of GVHD after CBT could be due to insufficient T-lymphocyte and NK cell function [40-42].

The sources for bone marrow transplantation are bone marrow, CB, and APB. Cells necessary for short- and long-term reconstitution after transplantation are thought to exist among the mononuclear cell population expressing CD34. CD34 stem cells can be isolated from $\mathrm{CB}$, bone marrow, and APB and all three sources are deemed to have sufficient capacity for reconstitution of the hematopoietic system [43]. In the present study the CD34 cell ratio in CB was similar to that in MPB. Although most studies reported similar results, CD34 stem cells obtained from these sources had qualitative and quantitative differences $[44,45]$.

Many studies reported that $\mathrm{CB}$ NK cells have lower-level cytotoxic function against traditional cell lines, such as K562 and Daudi, than MPB NK cells; however, low-level CB NK cell cytotoxic function may be increased by various cytokines, such as IFN- $\gamma$, IL-2, IL-7, IL-12, and IL-15 individually and in 
combination. In CBT the existence or absence of several cytokines is considered to lower the incidence of GVHD [46,47]. In the present study NK activity was measured using flow cytometry and FITC- or CFDA-labeled K562 target cells. According to the present results, no difference in cytotoxicity was observed between MPB and CB samples, in contrast to studies that reported suppression of NK cell cytotoxicity in postpartum women [48]. The same suppression pattern was observed in NK cells from premature infants, as compared to those from full-term infants [49-51], indicating that not only the number, but also the function differs according to the type of delivery.

The standard method for determining NK activity is the chromium-release assay; however, this assay is not a preferred method for use in clinical laboratories for a variety of reasons, e.g. it requires the use of radioactive chromium, which is very expensive and requires specialized handling and disposal. For these reasons a new flow cytometry-based method was developed for measuring NK cell activity. Flow cytometric assays avoid the problems associated with the use of radioactive methods, and are rapid and easier to standardize. The present results support the notion that flow cytometry could be a suitable alternative for measuring NK activity [23,52].

In conclusion, the results of the present study suggest that there is numerical and proportional variability between lymphocytes and their subgroups in CB and APB, although no significant difference was observed between these 2 samples, according to cytotoxic activity. The clinical relevance of these subsets for GVHD and the development of protective immunity in allogeneic CBT is substantial, and we are conducting ongoing prospective research.

\section{Conflict of interest statement}

None of the authors of this paper has a conflict of interest, including specific financial interests, relationships, and/or affiliations relevant to the subject matter or materials included.

\section{References}

1. Locatelli F, Rocha V, Chastang C, Arcese W, Michel G, Abecasis M, Messina C, Ortega J, Badell-Serra I, Plouvier E, Souillet G, Jouet JP, Pasquini R, Ferreira E, Garnier F, Gluckman E. Factors associated with outcome after cord blood transplantation in children with acute leukemia. Eurocord-Cord Blood Transplant Group. Blood 1999;93:3662-71.

2. Rocha V, Wagner JE Jr, Sobocinski KA, Klein JP, Zhang MJ, Horowitz MM, Gluckman E. Comparison of graft versus host disease in children transplanted with HLAidentical sibling umbilical cord blood versus bone marrow hematopoietic stem cells. N Engl J Med 2000;342:1846-54. [CrossRef]

3. Rocha V, Cornish J, Sievers EL, Filipovich A, Locatelli F, Peters C, Remberger M, Michel G, Arcese W, Dallorso S, Tiedemann K, Busca A, Chan KW, Kato S, Ortega J, Vowels M, Zander A, Souillet G, Oakill A, Woolfrey A, Pay AL, Green A, Garnier F, Ionescu I, Wernet P, Sirchia G, Rubinstein P, Chevret S, Gluckman E. Comparison of the outcomes of unrelated bone marrow or cord blood transplant in children with acute leukemia. Blood 2001;97:2962-71. [CrossRef]

4. Madrigal JA, Cohen SBA, Gluckman E, Charron DJ. Does cord blood transplantation results in lower graftversus-host disease? It takes more than two to tango. Hum Immunol 1997;56:1-5. [CrossRef]

5. Chalmers I, Janossy G, Contreras M, Navarrette C. Intracellular cytokine profile of cord and adult blood lymphocytes. Blood 1998;92:11-8.

6. Matthews NC, Wadhwa M, Bird C, Borras FE, Navarrete CV. Sustained expression of CD154 (CD40L) and proinflammatory cytokine production by alloantigen-stimulated umbilical cord blood T cells. J Immunol 2000;164: 6206-12.

7. D'Arena G, Musto P, Cascavilla N, Minervini MM, Di Giorgio G, Maglione A, Carotenuto M. Inability of cord blood T lymphocytes to perform Th1-like and Th2-like responses: implications for transplantation. J Hematother Stem Cell Res 1999;8:381-5. [CrossRef]

8. Harris DT, Schumacher MJ, LoCascio J, Booth A, Bard J, Boyse EA. Immunoreactivity of umbilical cord blood and post-partum maternal peripheral blood with regard to HLA-haploidentical transplantation. Bone Marrow Transplant 1994;14:63-8.

9. Webb BJ, Bochan MR, Montel A, Padillla LM, Brahmi Z. The lack of NK cytotoxicity associated with fresh HUCB may be due to the presence of soluble HLA in the serum. Cell Immunol 1994;159:246-61. [CrossRef]

10. Sautois B, Fillet G, Beguin Y. Comparative cytokine production by in vitro stimulated mononucleated cells from cord blood and adult blood. Exp Hematol 1997;25:103-8.

11. Hercend T, Takvorian T, Nowill A, Tantravahi R, Moingeon P, Anderson KC, Murray C, Bohuon C, Ythier A, Ritz J. Characterization of natural killer cells with anti-leukemia activity following allogeneic bone marrow transplantation. Blood 1986;67:722-8.

12. Slavin S, Naparstek E, Nagler A, Ackerstein A, Samuel S, Kapelushnik J, Brautbar C, Or R. Allogeneic cell therapy with donor peripheral blood cells and recombinant human interleukin-2 to treat leukemia relapse after allogeneic bone marrow transplantation. Blood 
1996:87:2195-204.

13. Mackinnon S, Papadopoulos EB, Carabasi MH, Reich L, Collins NH, Boulad F, Castro Malaspina $\mathrm{H}$, Childs BH, Gillio AP, Kernan NA. Adoptive immunotherapy evaluating escalating doses of donor leukocytes for relapse of chronic myeloid leukemia after bone marrow transplantation: separation of graft-vs-leukemia responses from graft-vs-host disease. Blood 1995;86:1261-8.

14. Weiden PL, Flournoy N, Thomas ED, Prentice R, Fefer A, Buckner CD, Storb R. Antileukemic effect of graft-vshost disease in human recipients of allogeneic-marrow grafts. N Engl J Med 1979;300:1068-73. [CrossRef]

15. Weiden PL, Sullivan KM, Flournoy N, Storb R, Thomas ED. Antileukemic effect of chronic graft-vs-host disease: contribution to improved survival after allogeneic marrow transplantation. N Engl J Med 1981;304:1529-33. [CrossRef]

16. Apperley JF, Jones L, Hale G, Waldmann H, Hows J, Rombos Y, Tsatalas C, Marcus RE, Goolden AW, Gordon-Smith EC. Bone marrow transplantation for patients with chronic myeloid leukaemia: T-cell depletion with Campath-1 reduces the incidence of graft-vshost disease but may increase the risk of leukaemic relapse. Bone Marrow Transplant 1986;1:53-66.

17. Bacigalupo A, Van Lint MT, Occhini D, Gualandi F, Lamparelli T, Sogno G, Tedone E, Frassoni F, Tong J, Marmont AM. Increased risk of leukemia relapse with high-dose cyclosporine A after allogeneic marrow transplantation for acute leukemia. Blood 1991;77:1423-8.

18. Gaddy J, Risdon G, Broxmeyer HE. Cord blood natural killer cells are functionally and phenotypically immature but readily respond to interleukin- 2 and interleukin-12. J Interferon Cytokine Res 1995;15:527-36. [CrossRef]

19. Condiotti R, Nagler A. Effect of interleukin-12 on antitumor activity of human umbilical cord blood and bone marrow cytotoxic cells. Exp Hematol 1998;26: 571-9.

20. Cicuttini FM, Martin M, Petrie HT, Boyd AW. A novel population of natural killer progenitor cells isolated from human umbilical cord blood. J Immunol 1993;151:29-37.

21. Nagler A, Peacock M, Tantoco M, Lamons D, Okarma TB, Okrongly DA. Red blood cell depletion and enrichment of CD34+ hematopoietic progenitor cells from human umbilical cord blood using soybean agglutinin and CD34 immunoselection. Exp Hematol 1994;22:1134-40.

22. Venema $H$, van den Berg $A P$, van Zanten $C$, van Son WJ, van der Giessen M, The TH. Natural killer cell responses in the renal transplant patients with cytomegalovirus infection. J Med Virol 1994;42:188-92. [CrossRef]

23. Hatam L, Schuval S, Bonagura VR. Flow cytometric analysis of natural killer cell function as a clinical assay. Cytometry 1994;16:59-68. [CrossRef]

24. Whiteside TL, Herberman RB. Role of human natural killer cells in health and disease. Clin Diagn Lab Immunol 1994;1:125-33.

25. Lanier Lewis L. Activating and inhibitory NK cell receptors. Adv Exp Med Biol 1998; 452: 13-8.
26. Colonna M. Fine-tuning NK cell responses: it's a family affair. Nat Immunol 2005;6:961-2. [CrossRef]

27. Orange JS, Ballas ZK. Natural killer cells in human health and disease. Clin Immunol 2006;118:1-10. [CrossRef]

28. Long EO. Regulation of immune responses through inhibitory receptors. Annu Rev Immunol 1999;17: 875-904. [CrossRef]

29. Mattis AE, Bernhardt G, Lipp M, Förster R. Analyzing cytotoxic $T$ lymphocyte activity: a simple and reliable flow cytometry-based assay. J Immunol Methods 1997;204:135-42. [CrossRef]

30. Kurtberg J, Laughlin M, Graham ML, Smith C, Olson $J F$, Halperin EC, Ciocci G, Carrier C, Stevens CE, Rubinstein P. Placental blood as a source of hematopoietic stem cells for transplantation into unrelated recipients. N Engl J Med 1996;335:157-66. [CrossRef]

31. Hunt DW, Huppert HI, Jiang HJ, Petty RE. Studies of human cord blood dendritic cells: Evidence for functional immaturity. Blood 1994;84:4333-43.

32. Cairo MS, Wagner EL, Fraser J, Cohen G, Van de Ven C, Carter SL, Kernan NA, Kurtzberg J . Characterization of banked umbilical cord blood hematopoietic progenitor cells and lymphocyte subsets and correlation with ethnicity, birth weight, sex, and type of delivery: a Cord Blood Transplantation (COBLT) Study report. Transfusion 2005;45:856-66. [CrossRef]

33. Szabolcs P, Park KD, Reese M, Marti L, Broadwater G, Kurtzberg J. Coexistent naive phenotype and higher cycling rate of cord blood T cells as compared to adult peripheral blood. Experimental Hematology 2003;31:708-14. [CrossRef]

34. Martin F, Kearney JF. B1 cells: similarities and differences with other B cell subsets. Curr Opin Immunol 2001;13:195-201. [CrossRef]

35. Hagihara M, Chargui J, Gansuvd B, Tsuchida F, Sato T, Hotta T, Kato S. Umbilical cord blood T Iymphocytes are induced to apoptosis after being allo-primed in vitro. Bone Marrow Transplant 1999;24:1229-33. [CrossRef]

36. Verneris MR, Miller JS. The phenotypic and functional characteristics of umbilical cord blood and peripheral blood natural killer cells. $\mathrm{Br}$ J Haematol. 2009;147: 185-91. [CrossRef]

37. Carayol G, Robin C, Bourhis J H, Bennaceur Griscelli A, Chouaib S, Coulombel L, Caignard A. NK cells differentiated from bone marrow, cord blood and peripheral blood stem cells exhibit similar phenotype and functions. Eur J Immunolog 1998;28:1991-2002. [CrossRef]

38. Wang $Y, X u H$, Zheng $X$, Wei $H$, Sun R, Tian Z. High expression of NKG2A/CD94 and low expression of granzyme B are associated with reduced cord blood NK cell activity. Cellular Molecular Immunology 2007;4:377-82.

39. Dalle JH, Menezes J, Wagner E, Blagdon M, Champagne J Champagne MA Duval M. Characterization of cord blood natural killer cells: implications for transplantation and neonatal infections. Pediatric Research 2005;57:649-55. [CrossRef] 
40. Bradstock KF, Kuxford C, Grimsley PG. Functional and phenotypic assessment of neonatal human leucocytes expressing natural killer cell-associated antigens. Immunol Cell Biol 1993;71:535-42. [CrossRef]

41. Rabian Herzog C, Lesage S, Gluckman E. Characterization of lymphocyte subpopulations in cord blood. Bone Marrow Transplant 1992;9:64-7.

42. Risdon G, Gaddy J, Stehman FB, Broxmeyer HE. Proliferative and cytotoxic responses of human cord blood T lymphocytes following allogenic stimulation. Cell Immunol 1994;154:14-24. [CrossRef]

43. Kessinger A. Autologous transplantation with peripheral blood stem cells. J Clin Apheresis 1990;5:97-9.

44. DiGiusto DL, Lee R, Moon J, Moss K, O'Toole T, Voytovich A, Webster D, Mule JJ. Hematopoietic potential of cryopreserved and ex vivo manipulated umbilical cord blood progenitor cells evaluated in vitro and in vivo. Blood 1996;87:1261-71.

45. Sousa T, de Sousa ME, Godinho MI, Mendes C, Carvalhais A, Barbosa IL. Umbilical cord blood processing: Volume reduction and recovery of CD34+ cells. Bone marrow Transplant 1997;19:311-3. [CrossRef]

46. Lin SJ, Chao HC, Yan DC. Phenotypic changes of T lymphocyte subsets induced by IL-12 and IL-15 in umbilical cord vs adult peripheral blood mononuclear cells. Pediatr Allergy Immunol 2001;12:21-32 [CrossRef]
47. Lin SJ, Cheng PJ, Huang YJ, Kuo ML. Evaluation of cytotoxic function and apoptosis in IL-12/IL-15-treated umbilical cord or adult peripheral blood natural killer cells by a propidium-iodide based flow cytometry. Pediatr Allergy Immunol 2004;15:79-85. [CrossRef]

48. Groer M, El Badri N, Djeu J, Harrington M, Van Eepoel J. Suppression of natural killer cell cytotoxicity in postpartum women. Am J Reprod Immunol 2010;63:209-13. [CrossRef]

49. Sancho L, de la Hera A, Casas J, Vaquer S, Martinez C, Alvarez Mon M. Two different maturational stages of natural killer lymphocytes in human newborn infants. Journal of Pediatrics 1991;119:446-54. [CrossRef]

50. McDonald T, Sneed J, Valenski WR, Dockter M, Cooke $\mathrm{R}$, Herrod HG. Natural killer cell activity in very low birth weight infants. Pediatric Research 1992;31: 376-80. [CrossRef]

51. Georgeson GD, Szony BJ, Streitman K, Kovacs A, Kovacs L, Laszlo A. Natural killer cell cytotoxicity is deficient in newborns with sepsis and recurrent infections. European Journal of Pediatrics 2001;160:478-82. [CrossRef]

52. Godoy Ramirez K, Franck K, Gaines H. A novel method for the simultaneous assessment of natural killer cell conjugate formation and cytotoxicity at the single-cell level by multi-parameter flow cytometry. J Immunol Methods 2000;239:35-44. [CrossRef] 